\title{
EU and Ukraine Cooperation for Sustainable Environment: Historical and Legal Aspects
}

\author{
By Rinata Kazak ${ }^{1}$
}

\begin{abstract}
The article discusses various aspects of the legal maintaining of environmental sustainability. Ukraine as one of the largest countries in Europe with more, than 40 million population causes a huge effect on the environmental situation in Europe. Through the historical research the author highlights the 60 - 70th of the XX century as an active period of international cooperation between the EU and Ukraine. The evidence of this activity was the complex Soviet Ukraine Act on nature protection 1960 and Government Committee for Nature Protection established in 1968 with competence of cooperation with European Community environmental authorities. Within a few years, many countries filled the gap and made a great step towards sustainable development, declared by the Stockholm Conference (1972) and First Environmental Action Programme in Europe (1973). The author draws the parallel between the Ukrainian and EU legal bases. Modern Ukraine tends to the association with the EU, so this research of a big importance has theoretical and practical value for Ukraine.
\end{abstract}

Keywords: EU and Ukraine cooperation, environmental sustainability, historical and legal aspects.

\section{Introduction.}

Conception of sustainable development as socio-economic construct was rapidly transformed by the process of greening of public consciousness and scientific knowledge, caused by destructive consequences of industrial restoration after the World War II. The second half of the XX century required the legal securing of the environmental protection guidelines.

The «sustainable development» was defined by the Brundtland Commission (1987) as: "development that meets the needs of the present without compromising the ability of future generations to meet their own needs". A great role in this concept extending and approval in European law have played the international conventions and documents adopted at the national and local levels. Environmental sustainability depends on such elements, as biotic and abiotic factors with natural and anthropogenic origin. Consequently, in the author's opinion, one of the key factors of the maintaining the stability is the effective implementation of biological diversity conservation policy at the national, global and supranational levels.

The author believes that biodiversity is an essential element of environmental stability and a basic factor of the optimal functioning of ecosystems (Kazak, 2014). 
Author agrees with the statement that «the biological diversity is the sine qua non for the resilience of ecosystems and life forms and their ability to prevent and to recover from disasters and adverse conditions». (Chazournez, $\mathrm{n} / \mathrm{d}$ ) In accordance with many researchers, biodiversity can be regarded as a key determinant of sound ecosystem and its optimal functioning (Rapport, Constanza \& McMichael, 1998). Nowadays, the society is facing the challenge of biodiversity loss in Europe and in the world as a whole. The statistics estimated rates of species loss are 100-10 000 times higher than background rates (i.e. those typical in the fossil record) (Santamaria \& Mendez, 2012). That's why the formulation of the biodiversity conservation principles and methods and their legal providing is the priority matter. Currently, the loss of biological diversity as an urgent threat to the mankind survival and the problem of its conservation appears in the scope of the international commitments and treaties in the preliminary stage of environmental sustainability policy, and according to G.S. Rosenberg (2005) - have "the political overtones" (p. 91). The European Union has taken much for the providing the ecological sustainability of the European territory. This is the challenge and positive example for Ukraine as one of the largest countries in Europe with more, than 40 million population, which effect the entire environmental situation in Europe. That's why the article deals with the legal aspect of this issue in Ukraine and analyzes the legal methods for its solution in the second half of the twentieth century (as the period of its rapid evolution).

\section{Objectives of the study. Methodology.}

The objectives of the study are:

to analyze the international cooperation in the field of environmental legal support (in the second half of the XXth century);

to determine the features of international cooperation (in historical aspect);

to define the problem issues of the legal ensuring of the environmental sustainability in Ukraine;

to discuss possible ways-out of the environmental crisis by using the lawhistorical experience nowadays.

It would be appropriate to mention such methods of the study as historicalcomparative and legal analysis to identify the main features and patterns of the chosen period.

\section{Main body of the article.}

\subsection{Legal framework review.}

While analyzing the legal base of the second half of the XX century it would be appropriate to mention one of the basic legal acts of the pre-research period (1949). One of the first documents with environmental purpose and a tendency towards sustainable development, was the Council of Ministers Resolution "On the nature protection on the territory of the Ukrainian SSR" on July 3, 1949. It dealt with the environmental situation of the republic, and provided recommendations for the biodiversity and nature conservation. Evaluation of the time situation was unsatisfactory, the improper attention to the nature protection issues was paid, that entailed a destruction of pristine areas and 
their inhabitants (flora and fauna). Therefore, the attention in this legal act was paid to the rare wild animals and plant conservation because of their great importance for national economy, science and culture. Very small areas of national reserves were completely insufficient in order to ensure the natural resource preservation and restoration. This is precisely why, the issue of the nature protection gained the special significance and had become the object of care and attention of the Soviet government, public authorities and the entire population. In order to improve the environmental situation in the country the intense legal framework was established on this issue.

Consequently, in the XX century, functions of the nature conservation in the Ukrainian SSR were diverse. A remarkable feature is some covert changes of functions that the natural environment performed in society - from the pragmatic objectives for the purposes of cultural development. According to the provisions of the Resolution 1949, the preservation of wild animals and plant species Ukrainian legislators attributed as "the great importance to the national economy, science and culture". But, almost a decade later, in he Central Committee of the CPSU and the Ukrainian SSR Council of Ministers Resolution "On measures on the improvement of the Nature Conservation in USSR" of June 3, 1958 the environmental protection priorities changed the order of preferences. It was noted that all environmental assets of the republic were the nationwide property, which were used for "all-round development, to meet the increasing cultural and material needs of the workers." Among them were outlined: large quantity of the natural resources, waste forest range inhabited by many animals, water with various species of fish, etc.

In 1950s, in conjunction with the establishment of regulatory device, trends of the nature protection measures and the determination of the main ways of the natural diversity conservation, the number of activities was carrying on in the development and adoption of a single omnibus act in this field. On September 24, 1958, the Resolution of the Ukrainian SSR Presidium of Supreme Council "On the Draft Law on the nature protection of the Ukrainian SSR" was adopted. In the early 1960s in all Soviet republics were adopted such enactments. In Ukraine, the Law on the nature protection of the Ukrainian SSR was adopted on June 30, 1960.

It would be desirable to draw attention to this act not only by the reason of its complexity and basic nature, but because its was adopted more than a decade ahead of the adoption of the first Environmental Programme in the European Union (1973). This fact can serve as an example of increased constant attention of the Soviet Ukraine to the problems of sustainable environment.

One of the first acts reinforcing provisions on international cooperation in the field of nature conservation became art. 3 Council of Ministers Resolution of March 25, 1968 "The approval of Regulations of the Council of Ministers Government Committee on the Nature Protection," which highlighted the global scale of this issue. This article proposed the establishment of scientific and technical staff in the field of nature conservation and coordination of their activities with the socialist and other foreign countries. This interdepartmental scientific and technical agency was created in 1974 .

The following baseline act in the sphere of the environmental sustainability was the Central Committee of the Communist Party and the Ukrainian SSR Council of Ministers Resolution on May 8, 1973 "On strengthening the nature conservation and 
improvement of natural resources of the republic." We singled out this legal act specifically, as this document could become an interesting subject of historical and legal research, for the reason that it can be compared with the adopted in that year the first Environmental Programme of the European Union, which is defined by many scholars like a classic document in the field of environmental protection (Kalinichenko, n.d). This period could be singled out like the time of the profound international cooperation between the EU and Ukraine. Within a few years, many countries made an extensive step towards the global sustainable development - the Stockholm Conference (1972), the first EP of the European Union (1973) and the Soviet Union basic regulations (particularly in Ukraine). For instance, the Central Committee of the Communist Party and the Council of Ministers Resolution of May 8, 1973 could be pointed out. It dealt with the strengthening of the nature conservation by the public authorities and their duty to pay more attention to the issues of the environmental protection and rational use of natural resources in Ukraine.

We suppose that the special attention of the study should be paid to the goal of the nature protection of that historical period - «the recognition of the need to solve these vital issues not just for the Soviet people, but also for all mankind». For this purpose, the Council of Ministers resolved to pursue the aims of the global conservation and reproduction of the fish stocks, wild animals, birds and other beneficial living organisms and plants; rational hunting; increasing of the specially protected natural areas, including nature reserves and national parks.

Black page of the environmental history of the second half of the XX century became the Chernobyl Nuclear Disaster, which occurred on the territory of Ukraine on April 26, 1986. The aspiration not to jeopardize the sustainable development of Europe was reflected in Ukrainian legal acts. For instance, in accordance to the provisions of the Central Committee of the Communist Party of Ukraine and the USSR Council of Ministers resolution "On radical reorganization of to environmental protection the republic" on November 18, 1988 it was firstly used the term «ecological consequence». The relationships with the consequences of the Chernobyl disaster impact was confirmed by the provision of the resolution on the demand to take into account the environmental criteria and possible environmental consequences while the positioning of industrial facilities.

\subsection{Legal aspect of financial issues review.}

However, the active international cooperation in the environment protection issues had not only formal but also the practical financial aspects. In the provisions of the Ukrainian SSR Council of Ministers Resolution on October 24, 1984 "On signing the Protocol on long-term financing of the joint program of monitoring and evaluation of the spread of Long-range Transboundary Air Pollutants in Europe (EMEP)" was decreed to instruct the Ukrainian SSR Permanent Representative in the UN Office and other International Organizations in Geneva - Batiouk V.G. - to participate in the Second Work Session of the Convention Executive Body, that was held in Geneva (Switzerland) 25 - 28 September 1984 and to sign the Protocol on long-term financing of the Joint Program of the monitoring and evaluation of the spread of Long-range Transboundary Air Pollutants in Europe (EMEP). We suppose that this resolution indicates, firstly, the profound collaboration between Ukraine and European countries and, 
secondly, the practical character of the natural habitat protection. Therefore, the partnership occurred not only by means of the Convention's adopting, but also the development of financing programs on this issue.

Before adopting the Convention on Biological Diversity (1992) the feasibility study on this issue was held, including technical and financial feasibility. During the preliminary stage, in the Executive Summary of the Ad Hoc Working Group Of Experts On Biological Diversity (the third session, 9-13 July 1990) it was mentioned that the implementation of the global strategy required additional funds even though national states and development assistance agencies already expend billions of US dollars annually for nature protection and environmental management. Illustrative facts of the global biodiversity conservation issue are the vast financial cost ratio. Thus, the World Resources Institute has estimated the need for additional funds amounting to US\$20-50 billion per year over a decade for a global strategy; the World Wide Fund for Nature Conservation (UK) has estimated the need for an additional US\$ 100 million per year; and the Union of the Soviet socialist Republics has estimated its additional needs in terms of US\$ 1.00 billion per year (clause 4). This report also set out aspect of cooperation in financial matters: it was noted that the formation of the consensus on international priorities for maintaining biological diversity will require regional and international advisory meetings and consultations (clause 6). The financial costs of coordinating the International Biological Program (IBP) were estimated at US\$ 1-3 million per year and the costs of program coordination of the World Conservation Union (IUCN) at 2-3 million per year.

This financial data illustrate the great community concern about the biodiversity loss issues. After the adoption of the Declaration of the Ukraine independence, the state holds on the various activities on the environmental sustainability. However, the financial capacities reduced. As an example, according to the United Nations Environmental performance Reviews "Use of foreign financial resources in expenditure devoted to environmental" the total amount of the foreign direct investment (FDI) per capita in Ukraine for the period 1991-2004 (U.S. \$ 178) were lower than in the eight countries of Southeast Europe ${ }^{1}$ (U.S. \$ 507) and the Russian Federation (U.S. \$ 331). In 1997 in order to attract foreign investors, encourage dialogue with foreign companies and assist them in placing their investments in the country the Consultative Council on Foreign Investment was established by the Presidential Decree No 325-97. This legal act indicates the relentless attention of the Ukrainian authorities to the cooperation with the foreign countries in the financial aspect for solving the problems of sustainable development.

\subsection{Problematic issues discussion.}

As the engross attention to the environmental challenges is observed, it would be desirable to highlight some root problems of the legal biodiversity protection and environmental sustainability in Ukraine. Among the key issues of the legal ensuring of

1 Albania, Bulgaria, Bosnia and Herzegovina, the former Yugoslav Republic of Macedonia, Romania, Serbia and Montenegro, and Turkey. 
the environmental conservation in Ukraine it could be identified such as: (a) the Soviet legislative framework usage, which has several positive aspects, however, does not meet the current requirements of the environmental situation in Ukraine and Europe throughout; (b) the disordered borrowing of the European experience, without a proper analysis of the technical and economic opportunities for its implementation. Inter alia, the author highlights numerous problems of biodiversity conservation issue (as a key element of the sustainability), such as: (a) the lack of the terminological base clarity in this sphere; (b) too varied use of the term in different contexts; (c) the absence of the public awareness of the specific challenges of biodiversity protection; (d) the biodiversity elements are considered separately, without paying due attention to the integrated nature of this object. All these unresolved issues have the irresistible impact on the efficiency of the biodiversity conservation policy.

There is the growing realization that the decisions on development and sustainability depend on access to well-organized information (Johnson, Crain \& Sneary, 1998), raising public awareness about the environmental problems and cooperation between the government and public (Getman \& Lozo, 2014). That is why, in our opinion, the primary action and the possible way-out of biodiversity conservation problems is providing the extensive information on this issue and closer cooperation and coordination between Ukraine and European countries. The extensive information may be conceived as a key contribution to the development of the harmonized national legislation base, considering the international treaties and statements.

\section{Conclusions.}

In conclusion, examining exactly the second half of the XX century, some features of the given period should be noted. They are - the strengthening of environmental actions, the global scale of the issue, the increased attention to the practical aspect, and the large number of the environmentally focused international agreements and conventions. In the second half of the XX century the activity of Ukraine was aimed at its own environmental conservation, population health preservation and sustainable development.

Our future actions couldn't be infallible, thus, the salient point of the sustainable development in the field of environmental conservations is to take into account historical aspects of this issue.

As it could be seen, the modern establishment of the sustainable development in the environmental field preceded by a long process of the basic principles ensuring at the legal level. Since the second half of the XX century the close collaboration between Ukraine and other foreign countries has been observed in the economic, social, financial, legal, and, of course, the environmental aspects. Ukraine aspires to the development and establishment of the legal framework in order to the optimal functioning of all ecosystems. Ukraine is holding up as an example such legislative basis like the European Programmes, global conventions and general trends of the political community. But, at the same time, in Ukrainian history there were the successful examples in point for this urgent issue - the huge quantity of legal acts, integrated nature in eco-issues solution, the international cooperation establishment. All these make it necessary to undertake the 
further researches of the environmental sustainability not just by the nature study scientists, but also by the historians of law in the theoretical and practical aspects of its legal implementation.

Among other public problems, environmental issues are, in some way, a little bit in another dimension - this is due to the fact that the ecological problems are unaware the territorial boundaries, and environmental disasters are not painted in the national flag colors. This is - Our Common Future.

\section{Acknowledgments}

The author expresses gratitude to the Head of the Department of History of State and Law of Ukraine and Foreign Countries Vladimir Goncharenko and to the research supervisor Vyacheslav Lozo for the scientific guidelines and support.

\section{References}

Biological Diversity: Global Conservation Needs And Costs (1990) - Ad Hoc Working Group Of Experts On Biological Diversity, Third Session Geneva, 9-13 July 1990 Executive Summary by Jose I.

Dos R. Purtado- Available at - http://www.cbd.int/doc/meetings/iccbd/bdewg03/official/bdewg-03-03-en.pdf

Environmental performance reviews of the United Nations New York and Geneva, 2007, p. 120 Обзоры результативности экологической деятельности организация объединенных наций Нью- Йорк и Женева, 2007 год, стр. 120 - Available at -

http://www.un.org/ru/publications/pdfs/second_survey_of_economic_activity_results_ukraine_rus.pdf Getman, A. P., \& Lozo, V. I. (2014) Гетьман, А. П., Лозо, В. И., Правовые проблемы экологической политики Европейского Союза и Украины. Харьков: Право - 280 - 109

Kalinichenko, P. A. (n.d) Калиниченко П.А. Шестая программа действий Европейского сообщества в области окружающей среды. Комментарий - The article is available at http://eulaw.edu.ru/documents/legislation/okr_sreda/6progr.htm

Laurence Boisson de Chazournes (n.d) Convention On Biological Diversity And Its Protocol On Biosafety United Nations - Audiovisual Library of International Law http://legal.un.org/avl/pdf/ha/cpbcbd/cpbcbd_e.pdf.

Luis S. \& Pablo F. M. (2012) Evolution in biodiversity policy - current gaps and future needs// Evolutionary Applications by Blackwell Publishing 5 (2) , - pp. 202-218

Our Common Future (1987), United Nations World Commission on Environment and Development, UN Documents: Gathering a Body of Global Agreements has been compiled by the NGO Committee on Education of the Conference of NGOs - is available at http://conspect.nl/pdf/Our_Common_Future-Brundtland_Report_1987.pdf

Rapport, D. J., Constanza R, \& A. J. McMichael. (1998) Assessing ecosystem health. Trends in Ecology and Evolution 13, 397-402

Shitikov, V.K., \& Rosenberg, G.S. (2005) Шитиков, В.К., Розенберг Г.С. Оценка биоразнообразия: попытка формального обобщения. Количественные методы экологии и гидробиологии. Сб. науч. трудов, посвященный памяти А. И. Баканова - С. 91-129

Timothy H. J., Ian K. C., \& Martin V. S. (1998), Feasibility study for a harmonised information management infrastructure for biodiversity-related treaties, World conservation monitoring centre, 107p. The report is available at http://www.unep-wcmc.org/

Collection of the Resolutions of the Ukrainian SSR:

Постановление Совета Министров УССР от 3 июля 1949 г. «Об охране природы на территории УССР».

Постановление ЦК КП Украины и Совета Министров Украинской ССР от 3 июня 1958 года «О мероприятиях по улучшению охраны природы Украинской ССР» 
Постанова ЦК Компартії України і Ради Міністрів УРСР від 18 листопада 1988 "Про корінну перебудову справи охорони природи в республіці"

Президиум Верховного Совета УССР от 24 сентября 1958 г. «О проекте Закона об охране природыУкр ССР»

Постановление ЦК КПУ и СМ от 8 мая 1973 г. «Об усилении охраны природы и улучшении использования природных ресурсов республики». 